\title{
Artikulasi Manajemen Pendidikan Islam Berbasis Kitab Ta'lim al-Muta'allim di SMP Plus Ar Rahmat Bojonegoro
}

\author{
Nurotun Mumtahanah \\ Institut Agama Islam Al Hikma Tuban \\ E-mail: nengmumun76@gmail.com \\ Elok Nuriyyah Pratama \\ Institut Agama Islam Al Hikma Tuban \\ E-mail: eloknuriyyah@gmail.com
}

\author{
Ahmad Suyuthi \\ Universitas Islam Negeri Sunan Ampel Surabaya \\ E-mail: ahmadasuyuthi@gmail.com
}

\begin{abstract}
Abstrak: Sebagai salah satu problem yang sering muncul dalam proses pembelajaran tentang bagaimana pola hubungan antara guru dan peserta didik. Kaidah Kitab Ta'lim al-Muta'allim perlu diimplementasikan dalam lembaga pendidikan. Eksistensi pelaksanaan manajemen pendidikan yang terkandung dalam kitab Ta'lim al-Muta'allim sebagaimana yang diterapkan dalam lembagalembaga pendidikan. seperti apa yang sudah diterapkan oleh kepala sekolah. Hasil penelitian menunjukkan bahwa bahwa Manajemen Pendidikan dalam kitab Ta'limulmuta'allim sangatlah bagus diterapkan dalam lembaga pendidikan saat ini. Pengajaran tentang cara menjadi seorang siswa dan guru yang baik. Pemikiran dan keyakinan Syekh Az Zarnujitentankaifiyah etika menuntut ilmu yang itu semua dapat meraih kemanfaatan dan keberkahan ilmu.Manajemen pendidikan yang mengamalkan kaidah kitab Ta'limul al-Muta'allim di Ar Rahmat tentang Pembiasaan karakter yang di terapkan dalam kaidah ta'limul muta'allim adalah kejujuran, kedisiplinan, kerja keras, fokus kepada tujuan, pantang menyerah, kesederhanaan, menghargai proses, pentingnya keseimbangan ihtiar lahir dan batin, need of achievment, dan beberapa filosofi hidup dan motto yang berisi motivasi.Eksistensi manajemen pendidikan kitab Ta'lim al-Muta'allim di ArRahmat yang masih begitu eksis pelaksanaannya.

Kata kunci: Eksistensi Manajemen Pendidikan, Ta'lim al-Muta'allim.
\end{abstract}

\begin{abstract}
As one of the problems often arising in the learning process on the pattern of relationships between teachers and students, the rules of the so-called Ta'lim al-Muta'allim need to be implemented in educational institutions. The implementation of education management contained in the Ta'lim a-Muta'allim as applied in educational institutions as what implemented by the principal. The results of the study show that the education management in the Ta'limul Muta'allim is extremely important applied in educational institutions today. It teaches on how to be a good student and teacher. The thoughts of Syekh Az Zarnuji on the ethics of studying in addition to achieving the benefits and blessings of knowledge. Educational management that practices the rules as contained in the Ta'lim al-Muta'allim in Ar Rahmat about the character habituation is honesty, discipline, hard work, focus on goals, never give up, simplicity, respect for the process, the importance of balance of physical and
\end{abstract}


spiritual exercise, need of achievement, and several life philosophies and mottos that contain motivation.

Keywords: Existence of Education Management, Ta'lim al-Muta'allim.

\section{Pendahuluan}

Pendidikan modern menghendaki agar para peserta didik sebanyak mungkin dilibatkan dalam proses belajar mengajar, sehingga siswa tidak hanya mendapat materi dari guru tetapi juga usaha sendiri mencari sumber-sumber lain sebagai pengayaan dari ilmu yang diperoleh. Karena itu Pendidikan berperan mensosialisasikan kemampuan baru kepada mereka agar mampu mengantisipasi tuntutan masyarakat yang dinamik ${ }^{1}$

Sejatinya pendidikan adalah totalitas usaha dan hendaknya membiarkan anak didik tumbuh dan berkembang secara serasi antara tigaranah kecakapan (kognitif, afektif, psikomotorik). Untuk mengimplementasikan tiga macam kecakapan di atas disarankan pembelajaran afektif dengan mengklasifikasikan ke dalam bagian kecil berdasarkan taksonomi Blomm. Pertama aspek Kognitif bisa dilakukan denan proses transmisi ilmu agama sebanyakbanyaknya kepada anak didik. Kedua, aspek Afektif yang mengedepankan trasformasi dan internalisasi nilai-nilai agama dari pada transmisi kognitif semata. Ketiga, aspek Psikomotorik dengan upaya menekankan kemampuan anak didik untuk menumbuhkan motivasi dalam diri sendiri sehingga mampu menggerakkan, menjalankan, mengaktualisasikan ajaran agama yang telah terinternalisasikan dalam dirinya melalui aspek afeksi. Namun, dalam praktiknya transmisi nila-nilai yangdilakukan lebih menonjol pada aspek Kognitif (Pengetahuan), sedangkan aspek Afektif dan Psikomotorik kurang mendapat perhatian yang serius. Hal ini terjadi karena kekeliruan dalam orientasi sistem Pendidikan yang dipergunakan. Sistem Pendidikan kadang kadang terlalu beriorentasi pada materi pelajaran, sehingga kegiatan belajar mengajar (Pendidikan) hanya menjadi instrumen transmisi nilai-nilai materi konsep saja, tidak membentuk pada tatanan praktis. ${ }^{22}$

Secara umum Pendidikan Agama Islam di Sekolah bertujuan untuk menumbuhkan dan meningkatkan keimanan melalui pemberian dan pemupukan pengetahuan, penghayatan, pengamalan serta pengalaman peserta didik tentang Agama Islam sehingga menjadi manusia muslim yang terus berkembang dalam hal keimanan, ketakwaannya, berbangsa dan bernegara, serta untuk dapat melanjutkan ke jenjang Pendidikan yang lebih tinggi. ${ }^{33}$ Melalui Pendidikan, setiap manusia bisa mengetahui segala hal yang tampak dan yang tidak tampak, yang jauh apalagi dekat. Bahkan dengan Pendidikan, seorang manusia dapat menguasai dunia dan tidak terikat lagi oleh sekat-sekat yang membatasi dirinya. Al-Qur'an Surah Ar Rahman memaparkan:

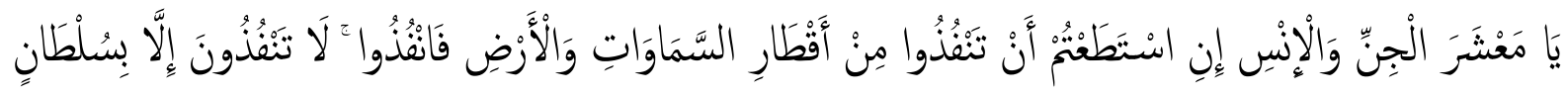

"Hai jama" ah jin dan manusia, jika kamu sanggup (melintasi) penjuru langit dan bumi, maka lintasilah, kamu tidak dapat menembusnya kecuali dengan kekuatan.” (Q.S Ar Rahman: 33).

\footnotetext{
${ }^{1}$ Muhaimin, Konsep Pendidikan Islam, Ramadhan (Solo, 2001), 25.

${ }^{2}$ Imam Tolkhah, Membuka Jendela Pendidikan (Jakarta: Raja Grafindo Persada, 2004), 54.

${ }^{3}$ Abdul Majid, Pendidikan Agama Islam Berbasisi Kompetensi (Bandung: PT. Remaja Rosdakarya, 2004$), 35$.
} 
Pendidikan dapat membentuk seseorang menjadi pintar dan berilmu sehingga mampu menjadi khalifah Allah SWT dimuka bumi ini. Seperti ungkapan Muhammad Abduh, seorang tokoh pembaharuan muslim yang terkenal, bahwa Pendidikan adalah hal terpenting dalam kehidupan manusia dan dapat merubah segala sesuatu. ${ }^{4}$ Jadi, tujuan Pendidikan Islam adalah mencetak manusia yang bertaqwa kepada Allah SWT dan berakhlak mulia, sehingga setiap amalanya di dasari oleh ilmu, dan ilmunya akan diamalkan kemudian akan tercipta akhlak yang karimah. Tujuan mulia Pendidikan Islam tersebut ada pada lembaga pendidikan. Di Lembaga Pendidikan tidak hanya diajarkan bagaimana cara menyerap ilmu, tapi juga bagaimana mengamalkan ilmu sehingga bisa diterapkan saat sudah keluar dari Lembaga Pendidikan. Salah satu ciri-ciri Lembaga Pendidikan yaitu mengajarkan tentang Kitab Kuning. Kitab Kuning merupakan salah satu fenomena dalam pondok pesantren dan mampu diterapkan di lembaga pendidikan, sehingga menjadi tradisi yang selalu melekat pada Lembaga Pendidikan. Kitab Kuning pada dasarnya merupakan istilah yang dimunculkan oleh kalangan luar pesantren untuk meremehkan kadar keilmuwan pesantren. Bagi mereka kitab kuning sebagai kitab yang memiliki kadar keilmuwan yang rendah dan menyebabkan stagnasi intelektual

Salah satu Kitab Kuning yang banyak diajarkan di pondok pesantren dan mampu diterapkan di Lembaga Pendidikan adalah kitab Ta'lim Al- Muta'allim. Kitab Karya AzZarnuji ini adalah salah satu kitab klasik, yang namanya dikenal dikalangan pesantren dan Lembaga Pendidikan di seluruh Indonesia. Kitab yang memberikan banyak konsep-konsep dan masalah Pendidikan dalam berbagai aspeknya ini banyak diajarkan bagi para penuntut pemula dalam lingkungan Lembaga Pendiikan. Kitab ini selalu diajarkan di semua pesantren dan Lembaga Pendidikan di Indonesia. Karena di dalamnya terdapat metode bagaimana beretika dalam belajar, bagaimana cara menghormati guru, bagaimana cara menghormati ilmu yang semuanya hanya untuk keberkahan dan kemanfaatan ilmu.

Daya tarik kitab ini yang banyak menjelaskan tentang ilmu pengetahuan menjadi nilai plus bagi para pendidik, terutama Lembaga Pendidikan di Indonesia, baik Lembaga Pendidikan Swasta, Negeri, maupun Lembaga Pendidikan Modern dengan menginternalisasikan nilai-nilai adab ke dalam pribadi siswa. Internalisasi ini merupaka proses pembangunan jiwa yang berasaskan konsep keimanan. Gagalnya sebuah Pendidikan karakter yang terjadi selama ini disebabkan karena Pendidikan karakter yang diajarkan minus nilai keimanan dan nilai adabnya. Sehingga, proses pembangunan akhaq terhalang bahkan hilang. Untuk membentuk penuntut ilmu yang berakhlaq dan beradab, maka Pendidikan Islam harus mengarahkan target Pendidikan pada pembangunan individu yang memahami tentang kedudukannya, baik kedudukan di hadapan tuhan, masyarakat, dan diri sendiri. Bahkan orangorang tersukses di dunia bisa berhasil dikarenakan lebih banyak didukung oleh kemampuan soft skill dari pada hard skill. Hal inimengisyaratkan bahwa mutu Pendidikan karakter siswa sangat penting ditingkatkan. ${ }^{75}$

Di dalam Kitab Ta'lim al-Muta'allim akan dibahas secara menyeluruh dan detail mengenai adab dalam menuntut ilmu. Sebagai salah satu problem yang sering muncul dalam

\footnotetext{
4 Muhammad Ammarah, Al-Imam Muhammad 'Abduh, Al-Imam Muhammad 'Abduh: Mujaddid Al-Islam (Beirut: Al-Muassassah Al-Islamiyyah Li Al-Dirasahwa Al-Nasyr, 1981), 34.

5 Jamal Ma'amurAsmani, Buku Pedoman Internalisasi Pendidikan Karakter Di Sekolah (Yogyakarta: Diva Press, 2012), 47.
} 
proses pembelajaran tentang bagaimana pola hubungan antara guru dan peserta didik. Jadi, garis besar dari kitab Ta'lim al-Muta'allim adalah berbagai Kaifiyah tentang etika menuntut ilmu yang dengan itu semua dapat meraih kemanfaatan dan keberkahan ilmu.

\section{Manajemen Pendidikan: Prinisp dan Perspektifnya dalam Islam}

Dalam Kamus Ilmiah Populer memberikan makna manajemen sebagai pengelolaan usaha, kepengurusan, ketatalaksanaan penggunaan sumber daya secara efektif untuk mencapai sasaran yang digunakan. ${ }^{6}$ Istilah manajemen berasal dari bahasa perancis kuno, management, yang memiliki arti seni melaksanakan dan mengatur. Manajemen belum memiliki definisi yang mapan dan diterima secara universal. Marry Parker Follet misalnya, mendefinisikan manajemen sebagai seni menyelesaikan pekerjaan melalui orang lain. Definisi ini berarti bahwa seorang manajer bertugas mengatur dan mengarahkan orang lain untuk mencapai tujuan organisasi. ${ }^{7}$

Secara prinsip dapat dilihat bahwa pada kenyataannya ilmu manajemen merupakan kombinasi ilmu dan seni dan tidak dalam proporsi yang tetap, tetapi dalam proporsi yang bermacam-macam. Konsep manajemen merupakan suatu konsep yang mencerminkan adanya kebiasaan yang dilakukan secara sadar dan terus menerus dalam organisasi.

Manajemen pendidikan islam adalah suatu proses pengelolaan lembaga pendidikan islam secara islami dengan cara menyiasati sumber-sumber belajar dan hal-hal lain yang terkait untuk mencapai tujuan pendidikan islam secara efektif dan efisien. Bahwasanya seorang pemimpin suatu lembaga atau sekolah perlu memiliki pengetahuan yang memadai tentang manajemen pendidikan dan prinsip-prinsipnya sebagai bekal kerja.

Manajemen bagi setiap organisasi atau lembaga merupakan unsur pokok yang harus dijalankan oleh setiap pimpinan organisasi atau lembaga tersebut. Para pimpinan tersebut bertindak sebagai manajer sehingga harus menggunakan sumber daya organisasi, keuangan, peralatan dan informasi serta sumber daya manusia dalam mencapai tujuan-tujuan yang telah ditetapkan sebelumnya.

Sumber daya manusia merupakan sumber daya terpenting bagi setiap organisasi. Tujuan-tujuan organisasi yang telah ditetapkan (state goals) mengandung arti bahwa para pemimpin atau manajer organisasi apapun berupaya untuk mencapai berbagai hasil akhir spesifik, tentu saja harus unik bagi masing-masing organisasi.

Manajemen adalah proses untuk mencapai tujuan-tujuan organisasi dengan melakukan kegiatan dari empat fungsi utama yaitu merencanakan (planning), mengorganisasikan (organizing), memimpin (leading), dan mengendalikan (controlling). Dengan demikian, manajemen adalah suatu kegiatan yangberkesinambungan

Titik persamaan dengan hakikat manajemen adalah al-tadbir (pengaturan). Kata ini merupakan derivasi dari kata dabbara (mengatur) yang banyak terdapat dalam Al Qur'an surah As-Sajdah ayat 05 yang berbunyi:

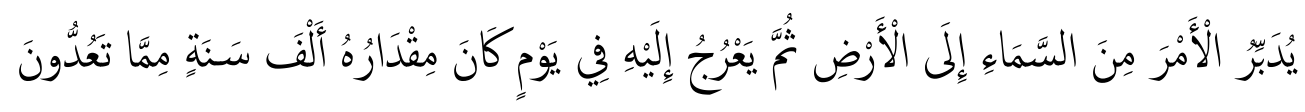

\footnotetext{
${ }^{6}$ Prus A. Partanto dan M. Dahlan Al Bary, Kamus Ilmiah Populer (Surabaya: Arloka, 1994), 434

${ }^{7}$ Undang Ahmad Kamaluding dan Muhammad Alfan, Etika Manajemen Islam (Bandung: Pustaka Setia,1994), 27.
} 
Artinya: Dia mengatur urusan dari langit ke bumi, kemudian (urusan) itu naik kepadanya dalam satu hari yang kadarnya adalah seribu tahun menurut perhitunganmu (As Sajdah: 05).

Dari isi kandungan ayat di atas dapatlah diketahui bahwa Allah swt adalahpengatur alam (manager). Keteraturan alam raya ini merupakan bukti kebesaranAllah swt dalam mengelola alam ini. Namun, karena manusia yang diciptakanAllah SWT telah dijadaikan sebagai khalifah di bumi, maka dia harus mengaturdan mengelola bumi dengan sebaik-baiknya sebagaimana Allah mengatur alamraya ini.

Mereka bertanya kepadamu tentang bulan sabit, mengapa bulan pada mulanya terlihat seperti bulan sabit, kecil, tetapi dari malam ke malam ia membesar hingga mencapai purnama, kemudian mengecil dan mengecil lagi, sampai menghilang dari pandangan? Katakanlah, "Bulan sabit itu adalah tanda-tanda waktu bagi manusia. Waktu dalam penggunaan Al-Qur'an adalah sebagai batas akhir suatu kesempatan untuk menyelesaikan pekerjaan ${ }^{148}$. Ia adalah kadar tertentu dari suatu masa. Dengan keadaan bulan seperti itu manusia dapat mengetahui dan merancang aktivitasnya sehingga dapat terlaksana sesuai dengan masa penyelesaian (waktu) yang tersedia, tidak terlambat, apalagi terabaikan dengan berlalunya waktu.

Al-Qur'an memerintahkan untuk memanfaatkan waktu semaksimal mungkin, bahkan dituntunnya umat manusia untuk mengisi seluruh waktunya dengan berbagai amal dengan mempergunakan semua daya yang dimilikinya.

Pendidikan adalah proses secara sistematis untuk mengubah tingkah laku seseorang utnuk mencapai tujuan organisasi. Menurut Undang-Undang RI Nomor 20 Tahun 2003 Bab 1 Pasal 1 ayat (1): Pendidkan adalah usaha sadar dan terencana untuk mewujudkan suasana belajar dan proses pembelajaran agar peserta didik secara aktif mengembangkan potensi dirinya untuk memiliki kekuatan spiritual keagamaan, pengendalian diri, kepribadian, kecerdasan, akhlak mulia, serta ketrampilan yang diperlukan dirinya, masyarakat, bangsa, dan Negara. $^{9}$

Berdasarkan dari pendapat beberapa ahli dapat disimpulkan bahwa manajemen pendidikan adalah suatu pola atau sistem koordinasi yang dilakukan dalam organisasi melalui proses perencanaan, pengorganisasian, pelaksanaan, dan pengawasan dengan memberdayakan semua kekuatan yang dimiliki dalam rangka pencapaian tujuan tertentu.Dalam manajemen terdapat prinsip-prinsip yang merupakan pedoman umum atau pegangan utama pelaksanaan aktifitas manajerial yang menentukan kesuksesan pengelolaan organisasi atau lembaga. Prinsip manajemen pendidikan antara lain:

1. Memprioritaskan tujuan di atas kepentingan pribadi dan kepentingan mekanisme kerja.

2. Mengkoordinasikan wewenang dan tanggung jawab.

3. Memberikan tanggung jawab pada personil sekolah hendaknya sesuai dengan sifat-sifat dan kemampuannya.

4. Mengenal secara baik faktor-faktor psikologis manusia

5. Relativitas nilai-nilai. ${ }^{10}$

Prinsip-prinsip di atas memiliki esensi bahwa manajemen dalam ilmu dan praktiknya harus memperhatikan tujuan, orang-orang, tugas-tugas, dan nilai nilai. Tujuan dirumuskan

\footnotetext{
${ }^{8}$ M. Quraish Shihab, Wawasan Al-Qur'an (Bandung: Mizan, 1996), 547.

${ }^{9}$ Undang-Undang RI Nomor 20 Tahun 2003 Bab 1 Pasal 1 ayat (1).

${ }^{10}$ Tim Dosen UPI, Manajemen Pendidikan (Bandung: Alfabeta, 2010), 90.
} 
dengan tepat sesuai dengan arah organisasi, tuntutan zaman, dan nilai-nilai yang berlaku. Tujuan suatu organisasi dapat dijabarkan dalambentuk visi, misi dan sasaran-sasaran. Ketiga bentuk tujuan itu harus dirumuskan dalam satu kekuatan tim yang memiliki komitmen terhadap kemajuan dan masa depan organisasi.

Para ahli manajemen memaparkan fungsi-fungsi manajemen sebagaimana tampak pada table berikut ${ }^{11}$

\section{Tabel 1}

Fungsi Manajemen Menurut Para Ahli

\begin{tabular}{|c|c|}
\hline Nama Ahli & Fungsi-Fungsi Manajemen \\
\hline Louis A.Allen & Leading, planning, organizing, controlling \\
\hline $\begin{array}{l}\text { Prajudi } \\
\text { Atmosudirjo }\end{array}$ & $\begin{array}{l}\text { Planning, } \\
\text { controlling }\end{array}$ \\
\hline John R. Beihsline & Planning, organizing, commanding, controlling \\
\hline Hanry Fayol & $\begin{array}{l}\text { Planning , organizing, commanding, coordinating, } \\
\text { Controlling }\end{array}$ \\
\hline Luther Gullich & $\begin{array}{l}\text { Planning, organizing, staffing, directing, } \\
\text { coordinating, reporting, budgeting }\end{array}$ \\
\hline $\begin{array}{l}\text { Kontz dan } \\
\text { O’Donnel }\end{array}$ & $\begin{array}{lll}\begin{array}{l}\text { Organizing, } \\
\text { controlling }\end{array} & \text { staffing, } & \text { directing, } \\
\end{array}$ \\
\hline WilliamNewman & $\begin{array}{l}\text { Planning, organizing, assembling resources, directing, } \\
\text { controlling }\end{array}$ \\
\hline Sondang P. Siagian & Planning, organizing, motivating, controlling \\
\hline George R. Terry & Planning, organizing, actuating, controlling \\
\hline Lyndal F. Urwick & $\begin{array}{l}\text { Forecasting, planning, organizing, commanding, } \\
\text { coordinating, controlling }\end{array}$ \\
\hline Winardi & $\begin{array}{l}\text { Planning, organizing, coordinating, actuating, } \\
\text { leading, communicating, controlling }\end{array}$ \\
\hline The Liang Gie & $\begin{array}{l}\text { Planning, decision making, directing, } \\
\text { coordinating, controlling, improving }\end{array}$ \\
\hline
\end{tabular}

Ada 13 pakar manajemen yang mengutarakan fungsi-fungsi manajemen. Dari semua fungsi tersebut, secara garis besar dapat dipahami bahwa seluruh kegiatan manajemen tidak dapat terlepas dari proses perencanaan, pengorganisasian, pelaksanaan, pengendalian dan evaluasi.

Untuk mempermudah pembahasan mengenai fungsi manajemen pendidikan, maka akan dijelaskan fungsi manajemen pendidikan sebagai berikut:

1. Fungsi Perencanaan (Planning)

Perencanaan adalah sebuah proses perdana ketika hendak melakukan pekerjaan baik dalam bentuk pemikiran maupun kerangka kerja agar tujuan yang hendak dicapai mendapatkan hasil yang optimal. Demikian pula halnya dalam pendidikan Islam perencanaan harus dijadikan langkah pertama yang benar-benar diperhatikan oleh para

\footnotetext{
${ }^{11}$ Saefullah, Manajemen Pendidikan Islam (Bandung: CV Pustaka Setia, 2012), 21
} 
manajer dan para pengelola pendidikan Islam. Sebab perencanaan merupakan bagian penting dari sebuah kesuksesan, kesalahan dalam menentukan perencanaan pendidikan Islam akan berakibat sangat patal bagi keberlangsungan pendidikan Islam.

Bahkan Allah memberikan arahan kepada setiap orang yang beriman untuk mendesain sebuah rencana apa yang akan dilakukan dikemudian hari, sebagaimana FirmanNya dalam Al Qur'an Surat Al Hasyr: 18 yang berbunyi:

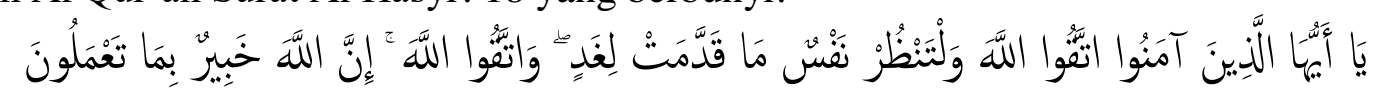

"Hai orang-orang yang beriman, bertakwalah kepada Allah dan hendaklah Setiap diri memperhatikan apa yang telah diperbuatnya untuk hari esok (akhirat); dan bertakwalah kepada Allah, Sesungguhnya Allah Maha mengetahui apa yang kamu kerjakan. (QS: AlHasyr ayat 18). ${ }^{21}$

Ketika menyusun sebuah perencanaan dalam pendidikan Islam tidaklah dilakukan hanya untuk mencapai tujuan dunia semata, tapi harus jauh lebih dari itumelampaui batasbatas target kehidupan duniawi. Arahkanlah perencanaan itu jugauntuk mencapai target kebahagiaan dunia dan akhirat, sehingga kedua-duanya bisadicapai secara seimbang.

2. Fungsi Pengorganisasian/pelaksanaan (organizing)

Ajaran Islam senantiasa mendorong para pemeluknya untuk melakukansegala sesuatu secara terorganisir dengan rapi, sebab bisa jadi suatu kebenaran yang tidak terorganisir dengan rapi akan dengan mudah bisa diluluhlantakan oleh kebathilan yang tersusun rapi.

Sebuah organisasi dalam manajemen pendidikan Islam akan dapat berjalandengan lancar dan sesuai dengan tujuan jika konsisten dengan prinsip-prinsip yangmendesain perjalanan organisasi yaitu Kebebasan, keadilan, dan musyawarah. Jikakesemua prinsip ini dapat diaplikasikan secara konsisten dalam proses pengelolaanlembaga pendidikan islam akan sangat membantu bagi para manajer pendidikanIslam.

Dari uraian di atas dapat difahami bahwa pengorganisasian merupakan fase kedua setelah perencanaan yang telah dibuat sebelumnya. Pengorganisasian terjadi karena pekerjaan yang perlu dilaksanakan itu terlalu berat untuk ditangani oleh satu orang saja. Dengan demikian diperlukan tenaga-tenaga bantuan dan terbentuklah suatu kelompok kerja yang efektif. Banyak pikiran, tangan, dan keterampilan dihimpun menjadi satu yang harus dikoordinasi bukan saja untuk diselesaikan tugas-tugas yang bersangkutan, tetapi juga untuk menciptakan kegunaan bagi masing-masing anggota kelompok tersebut terhadap keinginan keterampilan dan pengetahuan.

3. Fungsi Pengendalian (Directing)

Pengendalian adalah proses memberikan bimbingan kepada guru sehingga mereka menjadi guru yang berpengetahuan dan akan bekerja efektif menuju sasaran yang telah ditetapkan sebelumnya. Pengendalian bertujuan menjamin kinerja yang dicapai agar sesuai dengan rencana dan tujuan yang ditetapkan. Untuk kepentingan tersebut, penilaian dan pengendalian perlu membandingkan kinerja aktual dengan kinerja standar. Guru sebagai manajer pembelajaran harus mengambil strategi dan tindakan perbaikan apabila terdapat kesenjangan antara proses pembelajaran yang terjadi secara aktual dengan yang telah direncanakan dalam program pembelajaran.

Dalam manajemen pendidikan Islam, agar isi pengarahan yang diberikan kepada orang yang diberi pengarahan dapat dilaksanakan dengan baik makaseorang pengarah 
setidaknya harus memperhatikan beberapa prinsip berikut, yaituKeteladanan, konsistensi, keterbukaan, kelembutan, dan kebijakan. Isi pengarahan baik yang berupa perintah, larangan, maupun bimbingan hendaknya tidak memberatkan dan diluar kemampuan sipenerima arahan, sebab jika hal itu terjadi maka jangan berharap isi pengarahan itu dapat dilaksanakan dengan baik oleh sipenerima pengarahan.

Dengan demikian dapatlah disimpulkan bahwa fungsi pengendalian dalam tata kelola manajemen pendidikan adalah proses bimbingan yang didasari prinsip-prinsip religius kepada rekan kerja, sehingga orang tersebut mau melaksanakan tugasnya dengan sungguhsungguh dan bersemangat disertai keikhlasan yang sangat mendalam.

4. Fungsi Pengawasan (Controlling)

Pengawasan adalah keseluruhan upaya pengamatan pelaksanaan kegiatan operasional guna menjamin bahwa kegiatan tersebut sesuai dengan rencana yang telah ditetapkan sebelumnya. Bahkan Didin dan Hendri menyatakan bahwa dalam pandangan Islam pengawasan dilakukan untuk meluruskan yang tidak lurus, mengoreksi yang salah dan membenarkan yang hak.

Dalam pendidikan Islam pengawasan didefinisikan sebagai proses pemantauan yang terus menerus untuk menjamin terlaksananya perencanaan secara konsekwen baik yang bersifat materil maupun spirituil. ${ }^{12}$

Pengawasan dalam pendidikan Islam mempunyai karakteristik sebagai berikut: pengawasan bersifat material dan spiritual, monitoring bukan hanya manajer, tetapi juga Allah SWT, menggunakan metode yang manusiawi yang menjunjung martabat manusia. Dengan karakterisrik tersebut dapat dipahami bahwa pelaksana berbagai perencaan yang telah disepakati akan bertanggung jawab kepada manajernya dan Allah sebagai pengawas yang Maha Mengetahui. Di sisi lain pengawasan dalam konsep Islam lebih mengutamakan menggunakan pendekatan manusiawi, pendekatan yang dijiwai oleh nilai-nilai keislaman.

\section{Ta'lim al-Muta'allim: Tinjauan Konten}

Pengertian Kitab Ta'lim al-Muta'allim menurut Syekh Az-Zarnuji adalah sebuah kitab kecil yang mengajarkan tentang cara menjadi santri (siswa) dan guru (kyai) yang baik. Kitab Ta'lim al-Muta'allim merupakan satu-satunya karya Syekh Az-Zarnuji yang sampai sekarang masih ada. Kitab ini telah diberi syarah oleh Ibrahim bin Ismail yang diterbitkan pada tahun 996 H. kepopuleran kitab Ta'limulMuta'allim, telah diaui oleh ilmuan Barat dan Timur. ${ }^{13}$

Muhammad bin Abdul Qadir Ahmad menilainya sebagai karya munumental, yang mana orang alim seperti Az-Zarnuji pada saat itu hidupnya disibukkan dalam dunia pendidikan, sehingga dalam hidupnya sebagaimana Muhammad bin Abdul Qadir Ahmad hanya menulis sebuah buku. Tetapi pendapat lain mengatakanbahwa kemungkinan karya lain Az-Zarnuji ikut hangus terbakar karena penyerbuan bangsa Mongol yang dipimpin oleh Jenghis Khan, yang menghancurkan dan menaklukkan Persia Timur, Khurasan dan Transoxiana yang merupakan

\footnotetext{
${ }^{12}$ DidinHafidudin dan Hendri Tanjung, Manajemen Syariah dalam Prkatik (Gema Insani:Jakarta, 2003), 23.

${ }^{13}$ Nurul Huda, Konsep Belajar Dalam Kitab Ta'lim al-Muta'allim (Semarang: Pusat Penelitian IAIN Walisongo, 2000), 1 .
} 
daerah terkaya, termakmur dan berbudaya Persia yang cukup maju, hancur lebur berantakan, tinggal puing-puingnya. ${ }^{14}$

Kitab Ta'lim al-Muta'allim pertama kali dicetak di Jerman pada tahun 1709 M oleh Ralandus, di Labsak tahun 1839 M oleh Kaspari dengan tambahan muqaddimah oleh Plessner, di Marssadabad tahun 1265 H, di Qazan tahun 1898 M menjadi 32 halaman, dan tahun 1901 M menjadi 35 halaman dengan tambahan sedikit penjelasan atau syarah dibagian belakang, di Tunisia tahun $1286 \mathrm{H}$ menjadi 40 halaman, Tunisia Astanah tahun $1292 \mathrm{H}$ menjadi 46 halaman, dan tahun $1307 \mathrm{H}$ dan $1311 \mathrm{H}$ menjadi 52 halaman.

Dalam wujud naskah berharakat (musyakkalah), dapat ditemukan dari penerbit alMiftah, Surabaya. Kitab Ta'limulMuta'allim juga telah disyarahi menjadi satu kitab baru tetapi tanpa judul sendiri oleh Asy-Syaikh Ibrahim bin Ismail dan selesai ditulis pada tahun 996 H. Kitab ini banyak penggemarnya dan mendapat tempat selayaknya di lingkungan pelajar maupun guru. Terutama pada masa pemerintahan Murad Khan bin Salim Khan (abad $16 \mathrm{M}$ ). Kitab ini juga telah disadur dalam bentuk nadzam (puisi, pantun) yang diubah dengan bahr rojaz menjadi 269 bait oleh Ahmad Zaini, Solo Jawa Tengah. Naskahnya pernahditerbitan oleh MaktabahNabhaniyahKubro, Surabaya Jawa Timur atas nama penerbit Musthafa Babil Halabi Mesir, di bawah tashih Ahmad Sa'ad Ali seorang ulama' Al Azhar dan ketua Lajnah Tashih. ${ }^{15}$

Adapun materi pembahasan yang dipaparkan dalam kitab pedagogi tradisional dalam Islam ini terdiri dari 13 bab, yaitu:

1. Fasal tentang pengertian ilmu dan serta fiqh tentang keutamaannya

2. Fasal tentang niat di waktu belajar

3. Fasal tentang memilih ilmu, guru, teman, dan mengenai ketabahan

4. Fasal tentang menghormati ilmu dan ulama'

5. Fasal tentang tekun, kontinuitas dan minat

6. Fasal tentang permulaan, ukuran dan tata tertib belajar

7. Fasal tentang tawakkal

8. Fasal tentang pendapatan buah hasil ilmu

9. Fasal tentang kasih sayang dan nasihat

10. Fasal tentang istifadah

11. Fasal tentang wara' di kala belajar

12. Fasal tentang penyebab hafal dan lupa

13. Fasal tentang pendatang dan penghalang rizki, serta pemanjang danpengurang ilmu

Kitab Ta"lim al-Muta'allim diakhiri dengan bab yang ke-13 yang berisi tentang pendatang dan penghalang rizki, serta pemanjang dan pengurang umur. Setelah itu beliau mengucapkan rasa syukur kepada Allah yang telah mengajarkan manusia sesuatu yang tidak diketahuinya, yang memberikan nikmat dan kemulyaannya dengan adanya petunjuk. Dengan adanya kitab Ta'lim al- Muta'allimyang ditulis Syekh Ibrahim bin Ismail al-Zarnuji semoga dapat memberi manfaat kepada para penuntut ilmu. ${ }^{16}$

\footnotetext{
14 Muhammad Abdurrahman Khan, Sumbangan Umat Islam terhadap Ilmu Pengetahuan danKebudayaan (Bandung: Rosdakarya, 2005), 60

${ }^{15}$ M. Athiyah al-Abrasyi, Beberapa Pemikiran Pendidikan Islam (Yogyakarta: Titian Ilahi Press, 2010 ), 5.

${ }^{16}$ Nurul Huda, Konsep Belajar Dalam Kitab Ta'lim al-Muta'allim (Semarang: Pusat Penelitian IAIN Walisongo, 2000), 12.
} 
Pemikiran Syekh Az-Zarnnuji dalam kitabnya lebih kepada tujuan pembelajaran mencari ilmu untuk menghilangkan kebodohan dari anggota masyarakat (mencerdaskan masyarakat) menghidupkan nilai-nilai agama, dan melestarikan agama islam adalah merupakan tujuantujuan sosial karena dengan tiga tujuan tersebut berkaitan dengan kehidupan masyarkat sebagai keseluruhan, dengan tingkah laku masyarkatpada umumnya. Dari tujuan-tujuan ini Syekh Az-Zarnuji melihat bahwa keshalehan dan kecerdasan itu tidak hanya shaleh dan cerdas untuk diri sendiri, tetapi harus mampu mentranspormasikannya kedalam kehidupan bermasyarkat.

Sedangkan tujuan profesional, berhubungan dengan seseorang mencapai ilmu itu ialah menguasai ilmu yang berimplikasi pada pencapaian kedudukan. Namun kedudukan yang telah dicapai itu adalah dengan tujuan-tujuan kemaslahatan umat secara keseluruhan. Memperoleh kedudukan di masyarakattidak lain haruslah dengan ilmu dan menguasainya. Baik tujuan individual, sosisal dan profesional haruslah atas dasar memperoleh keridaan Allah dan kebahagiaan akherat.

Untuk itulah nampaknya Syekh Az-Zarnuji menempatkan mencari rida Allah dan kebahagiaan akherat menjadi awal dari segala tujuan (nilai sentral) bagi pembelajar. Jika tujuan memperoleh dibagi kepada empat yakni pertama, ilmu untuk ilmu (kegemaran dan hobi). Kedua, sebagai penghubung kesenangan materi. Ketiga, sebagai penghubung memajukan kebudayaan dan peradaban manusia. Keempat, mecari rida Allah dan kebahaagian akherat, maka yang terakhir ini sebagai tujuan sentral, sedangkan tujuan lainnya sebagai tujuan instrumental.

Tujuan pembelajar meperoleh ilmu yang di kemukakan syekh az-Zarnuji jika dilihat dari aliran pendidikan islam yang dikemukakan oleh Ridha, maka syekh az-Zarnuji termasuk dalam aliran konservatif religius. Ridha mengatakan, disamping lahirnya teori pendidikan berdasar pada hakikat fitrah dalam al qur'an, juga orientasi keagaman dan filsafat negara dajlam menafsirkan realitas dunia, fenomena dan eksistensi manusia melahirkam pemikiran pendidikan islam terutama menentukan: tujuan, ruang lingkup dan pembagian ilmu.

Dalam syarah kitab Ta'limulMuta'allim beliau juga menjelaskan tujuan penyusunan kitabnya:

"Seseorang yang menuntut ilmu harus bertujuan mengharap ridhaAllah, mencari kebahagiaan di akhirat, menghilangkan kebodohan baik dari dirinya sendiri maupun dari orang lain, menghidupkan agama, dan melestarikan Islam. Karena Islam itu dapat lestari, kalau pemeluknya berilmu. Zuhud dan takwa tidak sah tanpa disertai ilmu'. ${ }^{172}$

Syekh Burhanuddin menukil perkataan ulama sebuah syair: "orang alimyang durhaka bahayanya besar, tetapi orang bodoh yang tekun beribadah justrulebih besar bahayanya dibandingkan orang alim tadi. Keduanya adalah penyebab fitnah di kalangan umat, dan tidak layak dijadikan panutan. ${ }^{18}$

\section{Manajemen Pendidikan dalam kitab Ta'lim al-Muta'allim}

Di dalam Kitab Ta'lim al-muta'allim akan dibahas secara menyeluruh bagaimana Kaidah Kitab yang terkandung di dalamnya. Manajemen pendidikan dalam kitab KitabTa'lim

\footnotetext{
17 Terjemah Kitab Ta'lim al-Muta'allim (Lirboyo Press: 2010), 8.

${ }^{18}$ Syekh Al-Zarnuji, Ta'limulMuta'allim (Surabaya: Nurul Huda, tt), 3.
} 
al-muta'allim sangat bagus jika di terapkan dalam pembelajaran. Sebagai mana salah satu problem yang sering muncul dalam proses pembelajaran tentang bagaimana pola hubungan antara guru dan peserta didik. Jadi, garis besar dari kitab Ta'lim Al-Muta'allim adalah berbagai Kaifiyah tentang etika menuntut ilmu yang dengan itu semua dapat meraih kemanfaatan dan keberkahan ilmu.

Adapun penyelengaraan Manajemen Pendidikan dalam kitab Ta'lim al-Muta'allim secara garis besar adalah pendidikan pembelajaran pada peserta didik. Hal ini dapat dibuktikan bahwa kaidah yang terkandung dalam kitab Ta'limulMuta'allim diajarkan dalam lembaga ini yang menyangkut fungsi manajemen sendiri. Seperti perencanaan, pelaksanaan/ pengorganisasian, pengawasan, evaluasi, yakni sebagai berikut:

Fungsi pertama adalah perencanaan, dalam tahun pertama/ awal tahun SMP Plus Ar Rahmat Bojonegoro sudah menerapkan metode yang ada dalam kitabTa'limulMuta'allim. Yang mana SMP Plus Ar Rahmat sudah mempunyaiprogam untuk mendidik anak untuk mengedepankan akhlak dan budi luhur dalamkegiatan belajar mengajar di dalam kelas ataupun di luar kelas. Perencanaan dipandang sebagai fungsi sentral dari manajemen pendidikan dan harusberorientasi ke masa depan. Dalam implementasi pendidikan di dalam sekolah,perencanaan ini dituangkan dalam program pendidikan, yang berkaitan denganstrategi pembelajaran untuk mencapai tujuan secara efektif dan efisien seperti kedisiplinan siswa, kerendahan hati dan kerja keras. ${ }^{219}$

"untuk manajemen kami lebih menegedepankan pendekatan kekeluargaan dan niat baik dalam berjuang, sehingga dalam penerapan manajemen modern yang mengacu pada reward dan punishment tidak begitu kita kedepankan, yang jelas kita pengin cara belajar, pemanfaatan bidang IT, bidang yang digeluti kita ambil yang kekiniantapiruh perjuangan keihklasan, istiqomah dll kita ambil dari nilai-nilai pondok salaf., ${ }^{20}$

Dalam fungsi perencanaan ini siswa tidak boleh tidak/ wajib dalam niatmencari ilmu di sekolah, karena segala seseatu pekerjaan itu tergantung pada niatawal yang di utamakan. Siswa SMP Plus Ar Rahmat memiliki akhlaqulkarimah dalam bersikp dan berperilaku. Memiliki kesadaran dan kemampuan dalammelaksanakan sholat 5 waktu. Dan guru sebagai manajer pendidikan dan prosespembelajaran mampu mengambil keputusan yang tepat untuk mengelola berbagaisumber, untuk membentuk kompetensi siswa, serta mencapai tujuan yang telah diterapkan.

Fungsi kedua adalah pengorganisasian/pelaksanaan atau sering juga disebut implementasi, adalah proses yang memberikan kepastian bahwa program pembelajaran telah memiliki sumber daya manusia dan sarana, serta prasarana yang diperlukan dalam pelaksanaan, sehingga dapat membentuk kompetensi yang diinginkan. ${ }^{421}$ Pelaksanaan program ini ada pengorganisasian di setiap guru kelas dan guru mapel. Berikut tugas waka kesiswaan dalam membina siswanya.

"kita mendorong dan memotivasi siswa tentang pentingnya membaca referensi apapun di luar buku pelajaran dan penunjang mata pelajaran." 22

\footnotetext{
${ }^{19}$ I bid., 10.

${ }^{20}$ Syaroni, Wawancara, Bojonegoro, 22 Mei 2020.

${ }^{21}$ Syekh Al-Zarnuji, Ta 'limulMuta'allim, 10

${ }^{22}$ Widiyatmiko, Wawancara, Bojonegoro, 25 Mei 2020.
} 
Ini seperti pembagian pekerjaan ke dalam berbagai tugas yang harus dilakukan guru kepada siswa dalam pembelajaran. Secara mantap siswa menguasai perkembangan teknologi dengan baik dan memiliki kepribadian mandiri dan mampu mengembangkan potensi diri dari masing-masing siswa.

Fungsi ketiga adalah pengendalian, yang juga sering disebut penilaian, kegiatan pengakomodasian agar berjalan sesuai dengan tujuan awal yang dikehendaki. ${ }^{623}$ Untuk kepentingan tersebut, pengendalian perlu membandingkan kinerja aktual dengan kinerja standar. Pemberian tugas yang lebih spesifik, agar tujuan lebih mudah dilaksanakan. Berikut pengawasan dari guru mapel kepada siswa.

"Banyak sekali siswa yang juara olimpiade, khususnya tingkat nasional (OSN), siswa tersebut ketika ingin mengikuti lomba biasanya di dampingi oleh pihak lembaga, tetapi biasanya juga berangkat sendiri tanpa dampinganguru, karena dari setiap guru mapel telah memberikan yang terbaik kepada siswanya" 24

Guru sebagai manajer dalam pembelajaran harus mengambil strategi dantindakan perbaikan apabila terdapat kesenjangan antara proses pembelajaran yang terjadi secara aktual dengan yang telah direncanakan dalam program pembelajaran.

Fungsi keempat adalah pengawasan, atau kegiatan pengontrolan baiksupervisi maupun pengawasan program kinerja yang berpatokan kepada standaryang telah di buat. ${ }^{25}$ Dilakukan juga pengawasan guru terhadap siswa. Guru ataupengajar SMP Plus Ar Rahmat selalu memberikan pengawasan kepada siswa-siswanya dalam kegiatan belajar dan bertingkah laku, baik ketika siswa tersebutberada dilingkungan sekolah maupun diluar sekolah.

"SMP PLUS Ar Rahmat belum bisa menerima siswa lebih dari 60 dengan alasan agar kepala sekolah maupun guru itu tidak hnya kenal nama saja, melainkan mengetauhui setiap tingkah laku ataupun sikap siswa satu persatu, mulai dari belajarnya, dan kegiatannya sehari hari sehingga pengawasan dengan baik dapat terlaksana" 26

Table 2

Daftar kegiatan akademik dan non akademik SMP Plus Ar Rahmat ${ }^{27}$

\begin{tabular}{|c|l|c|l|}
\hline \multicolumn{2}{|c|}{ Kegiatan Akademik } & \multicolumn{2}{|c|}{ Kegiatan Non Akademik } \\
\hline 1 & $\begin{array}{l}\text { Bimbingan intensif untuk } \\
\text { OSN dan persiapan ujian } \\
\text { nasional }\end{array}$ & 1 & $\begin{array}{l}\text { Melaksanakan pembiasannislami } \\
\text { dalam kehidupan sehari-hari, dengan } \\
\text { program tahajud, dhuha, sholat 5 } \\
\text { waktu, dan membaca Al-Qur'an }\end{array}$ \\
\cline { 3 - 4 } & 2 & $\begin{array}{l}\text { Mencetak generasi islam yang mandiri } \\
\text { dan kuat dalam bidang science dan } \\
\text { agama }\end{array}$ \\
\hline
\end{tabular}

\footnotetext{
${ }^{23}$ Syekh Al-Zarnuji, Ta'limulMuta'allim,10

${ }^{24}$ Ananda Abdul Fatih, Wawancara, Bojonegoro, 04 Januari 2020.

${ }^{25}$ Syekh Al-Zarnuji, Ta'limulMuta'allim, 10

${ }^{26}$ Sya'roni, Wawancara, Bojonegoro, 22 Mei 2020.

${ }^{27}$ Daftar kegiatan akademik dan non akademik SMP Plus Ar Rahmat 2019/2020, Dokumentasi, Bojonegoro, 22 Mei 2020
} 
Evaluasi dilakukan pada tahapan akhir agar dapat diketahui tujuan pendidikan karakter yang berwujud pada perilaku yang diharapkan dapat tercapai. Juga dilakukan perbaikan apabila memang dibutuhkan. Mengevaluasi keberhasilan pengelolaan manajemen pendidikan.

\section{Artikulasi Manajemen Pendidikan berbasis Kitab Ta'lim al-Muta'allim di SMP Plus Ar- Rahmat Bojonegoro}

SMP Plus Ar-Rahmat adalah salah satu lembaga pendidikan yang masihbernaungan dalam pondok pesantren. Sebagai salah satu organisasi yang tidak lepas dari entitas kepemimpinan. Pendidikan modern SMP Plus Ar-Rahmat Bojonegoro adalah lembaga pendidikan modern yang mempunyai totalitas usaha dengan segala kehendaknya membiarkan anak didik tumbuh dan berkembang.

Table 3

Daftar Jenis Program SMP Plus Ar Rahmat Bojonegoro ${ }^{28}$

\begin{tabular}{|c|c|c|}
\hline Program & \multicolumn{2}{|r|}{ Langkah Program } \\
\hline \multirow{8}{*}{$\begin{array}{lr}\text { Berbudi Pekerti } & \text { Luhur, } \\
\text { Unggul dalam prestasi, } & \text { luas, } \\
\text { berpengetahuan } & \text { luan } \\
\text { menguasai IPTEK, yamg } \\
\text { dilandasi Iman dan Taqwa } \\
\text { kepada Allah SWT. }\end{array}$} & 1 & $\begin{array}{l}\text { Menumbuhkan penghayatan terhadap ajaran } \\
\text { agama melalui pembiasaan sehingga terbentuk } \\
\text { manusia yang berbudi luhur. }\end{array}$ \\
\hline & 2 & $\begin{array}{l}\text { Melaksanakan pembelajaran secara efektif dan } \\
\text { efesien }\end{array}$ \\
\hline & 3 & $\begin{array}{l}\text { Meningkat'kan profesionalisme guru melalui } \\
\text { MGMP dan Diklat }\end{array}$ \\
\hline & 4 & Menyediakan sarana dan prasarana memadai \\
\hline & 5 & $\begin{array}{l}\text { Meningkatkan prestasi belajar melalui } \\
\text { bimbingan khusus baik UN maupun OSN }\end{array}$ \\
\hline & 6 & $\begin{array}{l}\text { Meningkatkan efektifitas pembinaan olahraga } \\
\text { melalui kegiatan intrakurikuler dan } \\
\text { ekstrakulikuler }\end{array}$ \\
\hline & 7 & $\begin{array}{lrr}\text { Meningkatkan pembinaan kesenian } & \text { melalui } \\
\text { kegiatan-kegiatan } & \text { intrakulikuler } & \text { dan } \\
\text { ekstrakulikuler } & & \end{array}$ \\
\hline & 8 & Menumbuhkan budaya hidup bersih dan sehat \\
\hline
\end{tabular}

Dengan Pendidikan kitab Ta'limulMuta'allim membentuk seseorang menjadi pintar dan berilmu sehingga mampu menjadi khalifah Allah SWT dimuka bumi ini dengan keimanan melalui pemberian dan pemupukan pengetahuan, penghayatan, pengamalan serta pengalaman siswa tentang Agamanya sehingga menjadi manusia muslim yang terus berkembang dalam hal keimanan, ketakwaannya, berbangsa dan bernegara, serta untuk dapat melanjutkan ke jenjang Pendidikan yang lebih tinggi. ${ }^{1229}$

Pelaksanaan manajemen pendidikan pada proses planning, organizing,actualting dan controlling yang dikenal demgan P-O-A-C manajemen pendidikan.Dengan proses sebagai berikut:

\footnotetext{
${ }^{28}$ Daftar jenis program SMP Plus Ar Rahmat 2019/2020, Dokumentasi, Bojonegoro, 22 Mei 2020

${ }^{29}$ Abdul Majid, Pendidikan Agama Islam Berbasisi Kompetensi (PT. Remaja Rosdakarya, Bandung, 2004$), 35$.
} 
1. Pembagian alokasi waktu belajar pada setiap jenjang mata pelajaran.

2. Proses rekrutmen pengajar dan pembina, struktur organisasi di sekolah, pembinaan tenaga pendidik dan tenaga kependidikan.

3. Perencanaan penerimaan siswa baru, seleksi masuk calon siswa baru, kegiatan siswa selama 24 jam di asrama, peran santri sebagai kader ikatan pelajar, pembinaan akademik dan prestasi siswa.

4. Merencanakan standar kelayakan sarana dan prasarana pada sekolah, fasilitas dan komponen penunjang pendidikan, pengelolaan bangunan, fasilitas dan komponen penunjang pendidikan.

SMP Plus Ar-Rahmat adalah salah satu lembaga pendidikan yang masih bernaungan dalam pondok pesantren. Sebagai salah satu organisasi yang tidak lepas dari entitas kepemimpinan. Pendidikan modern SMP Plus Ar-Rahmat Bojonegoro adalah lembaga pendidikan modern yang mempunyai totalitas usaha dengan segala kehendaknya membiarkan anak didik tumbuh dan berkembang.

Fungsi manajemen adalah perencanaan, Pada tahun pertama/ awal tahun SMP Plus Ar Rahmat Bojonegoro sudah menerapkan metode yang ada dalam kitab Ta'lim al-Muta'allim. Yang mana SMP Plus Ar Rahmat sudah mempunyaiprogam untuk mendidik anak untuk mengedepankan akhlak dan budi luhur dalam kegiatan belajar mengajar di dalam kelas ataupun di luar kelas. Perencanaan dipandang sebagai fungsi sentral dari manajemen pendidikan dan harus berorientasi ke masa depan. Dalam implementasi pendidikan di dalam sekolah, perencanaan ini dituangkan dalam program pendidikan, yang berkaitan dengan strategi pembelajaran untuk mencapai tujuan secara efektif dan efisien seperti kedisiplinan siswa, kerendahan hati dan kerja keras.

Dalam implementasi pendidikan di dalam sekolah, perencanaan ini dituangkan dalam program pendidikan, yang berkaitan dengan strategi pembelajaran untuk mencapai tujuan secara efektif dan efisien. dalam tahun pertama/ awal tahun SMP Plus Ar Rahmat Bojonegoro sudah menerapkan metode yang ada dalam kitab Ta'limulMuta'allim. Yang mana SMP Plus Ar Rahmat sudah mempunyai progam untuk mendidik anak untuk mengedepankan akhlak dan budi luhur dalam kegiatan belajar mengajar di dalam kelas ataupun di luarkelas. ${ }^{330}$

Fungsi kedua adalah pengorganisasian/pelaksanaan atau sering juga disebut implementasi, adalah proses yang memberikan kepastian bahwa program pembelajaran telah memiliki sumber daya manusia dan sarana, serta prasarana yang diperlukan dalam pelaksanaan, sehingga dapat membentuk kompetensi yang diinginkan. proses yang memberikan kepastian bahwa program pembelajarantelah memiliki sumber daya manusia dan sarana, serta prasarana yang diperlukan dalam pelaksanaan, sehingga dapat membentuk kompetensi yang diinginkan. ${ }^{431}$

Kegiatan pelaksanaan ini mencakup pengorganisasian dan kepemimpinan yang melibatkan penetuan berbagai kegiatan, seperti pembagian pekerjaan ke dalam berbagai tugas yang harus dilakukan guru dan peserta didik dalam pembelajaran. Berbagai kegiatan manajemen pelaksanaa program pembelajaran dibagi ke dalam bagian-bagian yang lebih kecil sesuai dengan kebutuhan.

\footnotetext{
${ }^{30}$ Syekh Az-Zarnuji, Kitab Ta'lim al-Muta'allim, 10.

${ }^{31}$ Ibid., 10
} 
Oleh karena itu upaya pengelolaan maupun pengembangan manajerial lembaga pendidikan islam merupakan suatu keniscayaan yang harus ada dan tidak dapat ditiadakan. Namun, penerapan manajemen pendidikan islam adakalanya menghadapi berbagai kendala, baik bersifat ekonomi, potensi, in put-out put pendidikan maupun aspek manajerial pengelolaan lembaga hingga pada rendahnya standar mutu kelulusan lembaga. Akibatnya tidak ada perencanaan yang matang, dominasi personal terlalu besar dalam penentuan pengambilan keputusan, yang berbuntut pada munculnya produk pengelolaan yang asal jadi, tidak memiliki fokus strategi yang terarah, dan cenderung ekslusif dalam pengembangannya.

Fungsi ketiga adalah pengendalian, yang juga sering disebut penilaian, kegiatan pengakomodasian agar berjalan sesuai dengan tujuan awal yang dikehendaki. Untuk kepentingan tersebut, penilaian dan pengendalian perlu membandingkan kinerja aktual dengan kinerja standar. Guru sebagai manajer pembelajaran harus mengambil strategi dan tindakan perbaikan apabila terdapatkesenjangan antara proses pembelajaran yang terjadi secara aktual dengan yang telah direncanakan dalam program pembelajaran.

Kegiatan pengakomodasian agar berjalan sesuai dengan tujuan awal yang dikehendaki. ${ }^{32}$ Untuk kepentingan tersebut, pengendalian perlu membandingkan kinerja aktual dengan kinerja standar. Pemberian tugas yang lebih spesifik, agar tujuan lebih mudah dilaksanakan

Fungsi keempat adalah pengawasan, adalah upaya untuk suatu kinerja yang berpatokan kepada standar yang telah di buat, juga dilakukan perbaikan apabilamemang dibutuhkan. Mengevaluasi keberhasilan manajemen pendidikan, dilakukan juga pengawasan guru terhadap siswa. kegiatan pengontrolan baik supervisi maupun pengawasan program kinerja yang berpatokan kepada standar yang telah di buat. ${ }^{33}$

Guru atau pengajar SMP Plus Ar Rahmat selalu memberikan pengawasan kepada siswasiswanya dalam kegiatan belajar dan bertingkah laku, baik ketika siswa tersebut berada dilingkungan sekolah maupun diluar sekolah. Evaluasi dilakukan pada tahapan akhir agar dapat diketahui tujuan pendidikan karakter yang berwujud pada perilaku yang diharapkan dapat tercapai.

Evaluasi dilakukan pada tahapan akhir agar dapat diketahui tujuan pendidikan karakter yang berwujud pada perilaku yang diharapkan dapat tercapai. Juga dilakukan perbaikan apabila memang dibutuhkan. Mengevaluasi keberhasilan pengelolaan manajemen pendidikan.

Tujuan pendidikan pada dasarnya adalah sebuah bagian dari tujuan pendidikan islam sendiri. Akan tetapi, tidak semua lembaga pendidikan terutama lingkup SMP yang menanamkan pendidikan Akhlaq tersebut dalam lingkup sekolah. Sebagai salah satu SMP Plus Ar Rahmat yang menerapkan pendidikan akhlaqdidalamnya yang dilaksanakan dengan menggunakan tata kelola manajemen yang baik.

Beberapa pelaksanaan manajemen pendidikan yang terkandung dalam kitabTa'limulMuta'allim di SMP Plus Ar Rahmat Bojonegoro salah satunya bertujuan:

1. Sebagai pengembangan keimanan dan ketakwaan kepada Allah SWT serta terbentuknya Akhlak mulia siswa seoptimal mungkin, yang telah di tanamkan lebih dahulu dalam lingkungan keluarga.

\footnotetext{
${ }^{32}$ Ibid.

${ }^{33}$ Ibid.
} 
2. Untuk penanaman nilai ajaran Islam sebagai pedoman mencapai kebahagiaan hidup di dunia dan akhirat serta penyesuaian mental siswa terhadap lingkungan fisik dan sosial melalui pendidikan agama Islam.

3. Sebagai pencegahan siswa dari hal-hal negatif budaya asing yang akan dihadapinya seharihari, dan sebagai pengajaran tentang ilmu pengetahuan keagamaan sehingga menjadi manusia muslim yang terus berkembang dalam hal keimanan, ketaqwaannya kepada Allah SWT serta berakhlak mulia dalam kehidupan pribadi, bermasyarakat.

Dengan Pendidikan kitab Ta'limulMuta'allim terdapat penjelasan setiap manusia bisa mengetahui segala hal yang tampak dan yang tidak tampak, yang jauh apalagi dekat. Bahkan, seorang manusia dapat menguasai dunia dan tidak terikat lagi oleh sekat-sekat yang membatasi dirinya, membentuk seseorang menjadi pintar dan berilmu sehingga mampu menjadi khalifah Allah SWT. ${ }^{734}$

\section{Penutup}

Dari hasil penelitian tentang eksistensi manajemen pendidikan dalam kitab ta'limulmuta'allim di lembaga pendidikan modern Ar Rahmat Bojonegoro serta melakukan wawancara dengan berbagai pihak dapat disimpulkan beberapa hal sebagai berikut; bahwa Manajemen Pendidikan dalam kitab Ta'lim al-Muta'allim sangatlah bagus diterapkan dalam lembaga pendidikan saat ini. Pengajaran tentang cara menjadi seorang siswa dan guru yang baik. Pemikiran dan keyakinan Syekh Az Zarnuji tentan kaifiyah etika menuntut ilmu yang itu semua dapat meraih kemanfaatan dan keberkahan ilmu.Manajemen pendidikan yang mengamalkan kaidah kitab ta'limul muta'allim di Ar Rahmat tentang Pembiasaan karakter yang di terapkan dalam kaidah ta'limul muta'allim adalah kejujuran, kedisiplinan, kerja keras, fokus kepada tujuan, pantang menyerah, kesederhanaan, menghargai proses, pentingnya keseimbangan ihtiar lahir dan batin, need of achievment, dan beberapa filosofi hidup dan motto yang berisi motivasi.Eksistensi manajemen pendidikan kitab ta'lim al-Muta'allim di ArRahmat yang masih begitu eksis pelaksanaannya. Dengan tata kelola manajemen pendidikan yang unik dan unggul pastilahlembaga yang unggul mempunyai tata kelola manajemen pendidikan yang baik.

\section{Daftar Rujukan}

'Ammarah, Muhammad. Al-Imam Muhammad 'Abduh: Mujaddid Al-Islam, Beirut: AlMuassassah Al-Islamiyyah Li Al-Dirasahwa Al-Nasyr, 1981.

Abidin, Zainal. The Phenomenological Movement, The Hague: MartinusNijhoff, 1971.

al-Abrasyi, M. Athiyah. Beberapa Pemikiran Pendidikan Islam, Yogyakarta: Titian Ilahi Press, 2010.

Alfan, Undang Ahmad Kamaluding dan Muhammad. Etika Manajemen Islam, Bandung: Pustaka Setia, 1994.

As'ad, Aliy. Bimbingan Bagi Penuntut Ilmu Pengetahuan TerjTa'lim Al-Muta'allim, Kudus: Menara Kudus.

\footnotetext{
${ }^{34}$ Abdul Majid, Pendidikan Agama Islam, 35.
} 
Asmani, Jamal Ma'amur. Buku Pedoman Internalisasi Pendidikan Karakter Di Sekolah, Yogyakarta: Diva Press, 2012.

Bagus, Lorens. Kamus Filsafat, Jakarta: Gramedia Pustaka Utama, 2005.

Bayrakli, Bayraktar. Eksistensi Manusia (terj. Suharsono), Perenial Press: Jakarta, 1996.

Farikhah, Siti. Manajemen Lembaga Pendidikan, Yogyakarta: AswajaPressindo, 2011.

Huda, Nurul. Konsep Belajar Dalam Kitab Ta'lim Al-muta'allim, Semarang: Pusat Penelitian IAIN Walisongo, 2000.

Khan, Muhammad Abdurrahman. Sumbangan Umat Islam terhadap Ilmu Pengetahuan danKebudayaan, Bandung: Rosdakarya, 2005.

Langgulung, Hasan. Pendidikan Menghadapi Abad 21, Jakarta; Pustaka al-Husna, 1988.

M. Plessner, al-Zarnuji dalam First Encyclopedia of Islam Vol. VIII, London: New York: E. J. Brillees, 1987.

Machali, Didin Kurniadin Dan Imam. Manajemen Pendidikan Konsep Dan PrinsipPengelolaan Pendidikan, Yogyakarta: AR-Ruzz Media, 2012.

Majid, Abdul. Pendidikan Agama Islam Berbasisi Kompetensi, PT. Remaja Rosdakarya, Bandung, 2004.

Maksudin, Pendidikan Karakter Non-Dikotomi, Yogyakarta: Pustaka Pelajar, 2013

Mochtar, Affandi. Kitab Kuning dan Tradisi Akademik Pesantren, Bekasi: Pustaka Isfahan, 2008.

Muhaimin, Konsep Pendidikan Islam, Ramadhan, Solo, 2001.

Muzairi, Eksistensialisme Jean Paul Sartre, Yogyakarta: Pusataka Pelajar, 2002.

Prus A. Partanto dan M. Dahlan Al Bary, Kamus Ilmiah Populer, Surabaya: Arloka, 1994.

Qomar, Mujamil. Pesantren: Dari Transformasi Metodologi Menuju Demokratisasi Institusi, Jakarta: Erlangga, 2006.

Saefullah. Manajemen Pendidikan Islam, Bandung: CV Pustaka Setia, 2012.

Said, Imam Ghazali. Ta 'limul Muta'allim Thariqut Ta'allim, Surabaya: Diyantama, 1997.

Shadily, hn M. Echols dan Hassan. Kamus Inggris Indonesia, Jakarta: Gramedia Pustaka Utama, 2014.

Shihab, M. Quraish. Wawasan Al-Qur'an, Bandung: Mizan, 1996.

Sholihin. Modernitas, Posmodernitas, dan Agama. Semarang: Walisongo Press.

Suhardan, Dadang. Dkk., Manajemen Pendidikan, Bandung: Alfabeta.

SukamtoSatoto, Pengaturan Eksistensi Dan Fungsi Badan Kepegawaan Negara, Disertasi, Surabaya: Universitas Airlangga, 2004.

Tafsir, Ahmad. Filsafat Umum; Akal dan Hati Sejak Thales Sampai Capra, Bandung: Rosda Karya, 2006.

Tanjung, Didin Hafidudin dan Hendri. Manajemen Syariah dalam Prkatik, Gema Insani: Jakarta, 2003.

Tim Dosen UPI, Manajemen Pendidikan, Bandung: Alfabeta, 2010.

Tirtarahardja, Umar dan S.L. La Sulo. Pengantar Pendidikan, Jakarta: Rineka Cipta, 2005.

Tolkhah, Imam. Membuka Jendela Pendidikan, Jakarta: Raja Grafindo Persada, 2004.

Undang-Undang RI Nomor 20 Tahun 2003 Bab 1 Pasal 1 ayat (1).

Yenny. Modul Perkuliahan Psikologi Kepribadian, Universitas Mercu Buana, 2015.

Zaenal, Veithzal Rivai. et. al., Islamic Human Capital Management, Jakarta: Raja Grafindo Persada, 2014. 
Zarnuji (al), Syekh. Ta'limulMuta'allim, Surabaya: Nurul Huda, tt 